\title{
Commercial Rodents in America: Standard Animals, Model Animals, and Biological Diversity
}

\author{
Cheryl A. Logan \\ Departments of Psychology and History, University of North Carolina Greensboro, Greensboro, NC, USA
}

\author{
Keywords \\ Behavior genetics $\cdot$ Big science $\cdot$ Donaldson . \\ Du Bois-Reymond · Engineering ideal · Greenman . \\ JAX mice $\cdot$ Little $\cdot$ Model animals $\cdot$ Standardization . \\ Wistar rats
}

\begin{abstract}
Rodents as standardized test animals were developed for commercial distribution in the USA between 1910 and the 1930s. The selective breeding of rats (Rattus norvegicus) and pure-bred mice (Mus musculus) at the Wistar Institute and the Jackson Memorial Laboratories eventually led to a decline in the diversity of species used in American medical and life sciences. The early driving figures, science administrator Milton Greenman and the scientists Henry Donaldson and Clarence Little, sought to standardize animals to render science and its application to humanity more precise. But their efforts were exaggerated in the USA through an expanding industrial and engineering ideal, culminating in a preference for Big Science. I explore the nineteenth century origins of this ideal in Emil Du Bois-Reymond's neurophysiology. This foundation later merged with increasing standardization, American commercialism, and the success of Big Science to transform animal laboratory "standards" into "model animals." Recent accounts of research with commercially bred
\end{abstract}

\section{KARGER}

() 2019 S. Karger AG, Basel

E-Mail karger@karger.com

www.karger.com/bbe mice reveal how findings can be co-constructed using human clinical data, as animal research is applied to humans. The neglect of evolutionary perspectives and the dominance of "models" may even have begun with the government's post-war emphasis on funding greater species access for large-scale biomedical research.

(c) 2019 S. Karger AG, Basel

\section{Introduction}

Modern experimental physiology flourished in urban laboratories in Germany in the second half of the nineteenth century. The reasons are complex, but two changes influenced the unprecedented precision that emerged there, raising physiology to the status of an independent discipline. One was the impact of the industrial revolution occurring in the large German cities of the time. A second was the underlying philosophy of a group of scientists, who, by the 1860s, drew heavily on the tools of that revolution. The pioneering Berlin neurophysiologist Emil Du Bois-Reymond was a member of this group [Dierig, 2006], which also included the physiologists Carl Ludwig and Ernst Brücke, and the physicist Hermann Helmholtz [Lenoir, 1993, 1998; Dierig, 2003; Finkelstein, 2013; Brain, 2016]. 
Berlin's industrial revolution overlapped with the early rise of experimentation in physiology. Analyzing Du Bois-Reymond's 5-decade-long career, Dierig [2003, p. $118]$ stresses the importance of the "technology-rich environment" provided by steam power, the telegraph, and Berlin's industrialists and machinists, who, from early on, surrounded Du Bois-Reymond's science. First conducted in his parents' home, then in his Berlin apartment, Du Bois-Reymond's neurophysiology, by 1877 , defined the newly constructed Physiological Institute at the University of Berlin. Dierig [2006] argues that nineteenth century physiology drew heavily on the ideals of physics and chemistry to integrate experimentation into neurophysiology while relying on the parallel changes in Berlin's revolution in work. The "transformation of the experimental workplace from [Du Bois-Reymond's] private parlor laboratory to a national institute of physiology" depended not just on genius and persistence, but on an "ensemble of very different actors and interlaced competencies that ... carried the huge upheavals ... in crafts, industry, and technology into the comparably open world of experimental physiology" [Dierig, 2006, p. 9].

The impact of urban industrialization on physiology did not create animal models. But it so thoroughly linked live animals to machines that their new hybrid manifestation altered the way science was done. Partly because of this, Du Bois-Reymond's work effectively transformed neurophysiology into a modern discipline, providing the basis for future brain study. However, the animals in that research became what Amman [1994] calls a "second nature": one whose relationship to unmodified nature remains a central topic, as scholars place test animals into broader experimental systems [Lynch, 1988; De Chadarevian and Hopwood, 2004; Creager, et al., 2007; Kirk, 2008; Rheinberger, 2010; Borck, 2012; Nicholson, 2013; Ankeny et al., 2014; Germain, 2014; Green et al., 2018]. I focus on the nineteenth and early twentieth century concept of standardization that, in the USA, first led to the development of "standard" animals and eventually to a few "model animals" whose dominance constricted species diversity in neurophysiology and genetics.

\section{Machines and Modern Physiology}

Prior to the widespread use of experimentation, anatomy dominated physiology in academic and private research institutes. That began to change around 1850. Early physiological experiments had used curare to immobilize animals during surgical procedures. However, because the drug also paralyzed the respiratory muscles, surgical assistants had to manually expand and contract animals' lungs to sustain life during a procedure. Manual respiration required that an assistant continuously crank or pedal bellows, forcing air into the lungs (in rabbits this involved 9-30 inhalations per minute [Dierig, 2003]). The difficulty of maintaining precisely constant motion yielded very imprecise physiological measures. This changed in 1869 when Carl Ludwig opened Germany's first physiology laboratory in Leipzig. By then gas lines underlay much of the city, and Ludwig's laboratory used a small gas motor - the Otto motor, built for use by craftsmen - to power a mechanical respirator. When connected to a mercury manometer and a rotating cylinder equipped with a stylus, the device became a kymograph - a machine that tracked changes in blood pressure in real time, rendering them as graphs [De Chadarevian, 1993; Dierig, 2003]. "By means of [such machines], artificially breathing dogs or rabbits were partly reproduced in their vital functions and partly natural mixes ["Mischwesen"] of the history of the relationship between nature and technology" [Dierig, 2006, p. 15]. The standardization brought by Ludwig's kymograph and the other "animal-machines" that followed revolutionized the measurement of physiological processes; they were keys to physiology's growth as a modern discipline. ${ }^{1}$

In the process, however, animals were "transformed into a technology for the laboratory's production purposes" [Dierig 2003, p. 124]; their "natural" nature as living beings was replaced by new entities that were part animal and part machine; Dierig [2003, p. 128] terms them "techno-organic hybrids." Research by an American scientist in Ludwig's Institute employed one such frog-machine (Fig. 1) in the analysis of successive contractions of muscle fibers in the reflex of a frog's leg.

Two dimensions of Du Bois-Reymond's approach deserve special emphasis. The first is the philosophy underlying what Du Bois-Reymond and his fellow physicalists called "organic physics." Meaning physiology, the term reflects their belief that physiological functions must be understood as fundamental physical processes of energy, matter, and motion, and nothing more. As such, their approach was an explicit challenge to vitalism, the view that there are forces in life - termed "Lebenskräfte" - which, while orderly, cannot be understood simply in terms of

\footnotetext{
${ }^{1}$ Sixteen physiology labs were built in Germany between 1870 and 1890 [Dierig, 2003]; the process occurred across Europe [see De Chadarevian, 1993; Todes, 2002; Brain, 2016].
} 


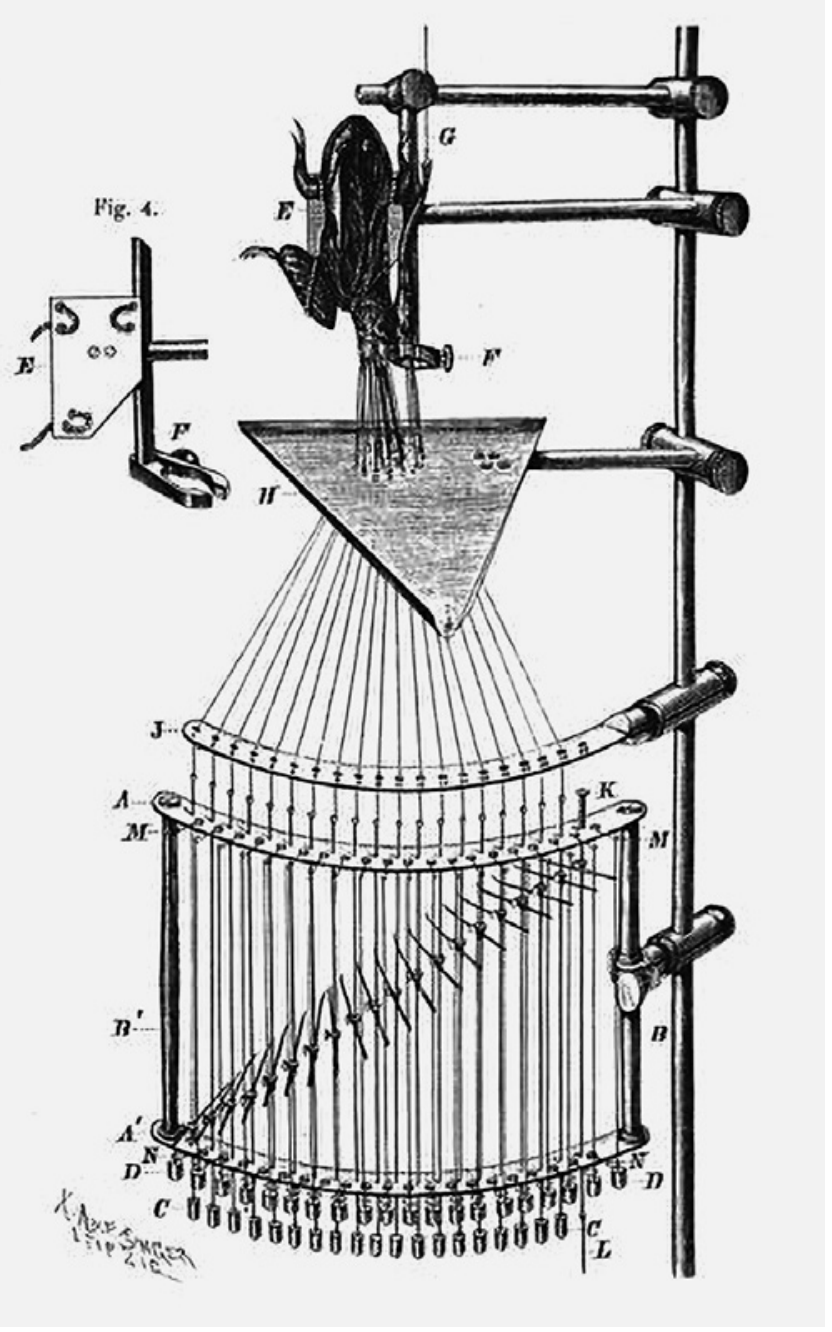

Fig. 1. The frog-machine used in Warren P. Lombard's research in Leipzig. From "Die räumliche und zeitliche Aufeinanderfolge reflektorisch contrahirter Muskeln.” Archiv für Anatomie und Physiologie. Physiologische Abteilung 1885, pp. 408-489.

physics and chemistry [Normandin and Wolfe, 2013]. The second was an aesthetic, based in Du Bois-Reymond's artistic sensibility, that stressed the union of science and fine art. For Du Bois-Reymond, that union both rendered animal-machines fundamental to science and made the mechanical beauty of electrical signaling in muscle twitches a feature of brain study [Dierig, 2006]. In the hands of Du Bois-Reymond, who loved drawing as well as machines and lawful regularity, that aesthetic fed the value of hybrid animal-machines [Finkelstein, 2013]. In doing so, it broadened the challenge to vitalism and the success of the mechanized laboratory. Du Bois-Reymond himself declared that his Institute would be run "like a factory" [quoted in Dierig, 2003], including animal-machines, a clear division of labor, and the stratified supervision of research.

\section{Du Bois-Reymond and Frogs}

$\mathrm{Du}$ Bois-Reymond's masterwork, Untersuchungen über thierische Elektricität (Investigations on Animal Electricity), was published and expanded in several volumes from 1848 to 1884 . Throughout, it relied heavily on frogs. In the early days, before instruments lengthened surgery time, frogs could live much longer during a procedure than could birds or mammals [Pera, 1992; Holmes, 1993]. Describing his research in an 1851 public lecture on animal movement, Du Bois-Reymond marveled that the frog itself was dead even as its nerves and legs - separated from the body and hooked to machines - remained alive. Du Bois-Reymond saw this as "a characteristic which the muscle draws on during life, and separated from the rest of the animal-machine or even with the destruction of this machine - death $-\ldots$ it survives ... ". He then posed the question of why, for nearly 200 years, this seemingly insignificant animal had been such a focus of physiological research. His answer is surprising: "This research is of value not to a frog as a frog." It works because the animal's parts survive death. "This kind of survival should permit you no more astonishment than that of a bouquet of flowers, which, when placed in a glass of water overnight, still opens a bud" [Du Bois-Reymond, quotes from Dierig, 2006, pp. 102-103]. However, this amazing anuran persistence did not by itself demonstrate generality. After his discovery in frogs of one of several laws of nerve-muscle action, the law of muscle current, he confirmed the relationship, repeating his measurements on no fewer than twelve other animal species, as well as on himself and such luminaries as Alexander von Humboldt [Finkelstein, 2013].

Du Bois-Reymond's approach reveals several dimensions of his use of animals. First, the animal is no longer the animal. Its parts have been extracted and integrated into a living machine: a hybrid, part life and part machine. Second, Du Bois-Reymond's experiments did not use frogs as models, but as something more like "preparations" [Rheinberger, 2010] or "instruments" [Germain, 2014] - which, while significant, might tell us nothing special about frogs. Because it represents no actual species, a frog-machine cannot be a template for complex attributes in other species. It models nothing, but reveals universals so general that the specifics of any taxon - am- 
phibian or mammal - are irrelevant. Third, the barrier between the organic and the inorganic is no barrier at all. Du Bois-Reymond's mentor, Johannes Müller was, like many earlier physiologists, a vitalist, who acknowledged an unbridgeable gulf between life and non-life. Du BoisReymond's approach instead reflected his physicalist reductionism, which, using techno-organic hybrids, could explain how neuromuscular processes were manifestations of the physical forces of motion - his "neurophysics" [Finkelstein, 2013, p. 69] - at work in all multicellular species. Importantly, however, Du Bois-Reymond did not reject evolution. Rather, he praised Darwin as "the Copernicus of the organic world." This was because, after Darwin, adaptations that had once been interpreted via an "untenable" doctrine of "vital energy" (vitalism) were "replaced by a mechanical process ... (of) natural selection" [Du Bois-Reymond, 1883]. Du Bois-Reymond saw Darwin as augmenting the physicalist's program.

The third point is central to Du Bois-Reymond's impact on the twentieth century. As a student, Du Bois-Reymond studied physics and physiology. In 1841, he and his friend, the physiologist Ernst Brücke, swore to uphold their belief that "no forces operate in the organism other than those common to physics and chemistry." If these could not explain the body, then "new forces ... of the same order as the physio-chemical (ones) inherent in matter" [Finkelstein, 2013, p. 64, quoting Du Bois-Reymond] must be added without constructing a boundary between the energies of physics and those of physiology. By 1845, after Du Bois-Reymond and Brücke had cofounded the Berlin Physical Society, Hermann Helmholtz (already author of the law of conservation of energy) and Carl Ludwig, Germany's premier physiologist, joined in the pledge, lending their prestige to the physicalists' challenge.

For Du Bois-Reymond, "inorganic steam machines and organic bodies belonged to one and the same material world. Nowhere in the world of bodies did forces operate independently of matter and its movements" [Dierig, 2006, p. 97]. His operating metaphor for the analysis of neural processes was the steam engine. Humanity was no exception [Borck, 2012]. For example, Helmholtz's theories of human hearing and vision used wireless telegraphy and self-regulating circuit breakers (pioneered by his friend Werner Siemens) to define the meaning of the neural processes enacting the "transmission, deciphering, and telegraphy of basic sounds" [Lenoir, 1993, p. 63]. In all life, physics could render physiology as applied physics. In this context, what Du Bois-Reymond regarded as "untenable" accounts of animals' evolutionary adapta-

Commercial Rodents: Standards and Models tions remained taboo. As a result, the very precision that brought modern standardization into neurophysiology also contributed to a tension between biomedical and mechanistic frameworks and the new organic and biological approaches to development and adaptation then also becoming prominent [Fangerau, 2017; Müller, 2017a].

\section{The Expansion of Experimentation}

Research done by the sea illustrates this tension. Marine stations were also centers for physiological research in the late nineteenth century. Many stressed investigations of morphogenesis in an atmosphere dominated by species diversity. The Naples Marine Station, founded in Italy in 1872, was the most famous. Naples invented the "table" system, which allowed institutions from around the world to reserve lab space to host visiting scientists in summer. Naples provided the animals used by these scientists, as nets dropped into the Bay of Naples periodically scooped up diverse creatures directly out of the sea. The animals were placed in tanks with circulating sea water, then sorted, and taken fresh to the tables for research. The system sustained a consistent emphasis on species diversity.

Before the turn of the twentieth century many pioneering American biologists - e.g., Thomas Hunt Morgan, Edmund Wilson, and Charles Otis Whitman - regularly spent summers at Naples [Benson, 1988; Maienschein, 1991]. There they even saw what the Naples Director, Anton Dohrn, called "the foundation of our ideas about the nervous system," including the neuron doctrine [quote in Florey, 1985, p. 142; see also Guillery, 2005]. Morgan's career illustrates the trajectory. Morgan, who gave us Drosophila, did not actually choose the animal. Though his later work surely stressed them, the flies were brought to his Columbia lab by someone else. And they were first considered "low status" material - pests appropriate primarily for graduate students' first-year projects. For Morgan himself, using many organisms was a "conscious strategy" [Kohler, 1994, pp. 27, 34]; he worked on over 50 different species.

However, the scope of the physicalists' impact was beginning to affect the USA. Bruce Fye [1987] describes how it transformed physiology at Harvard. Harvard physiologist Henry Bowditch, co-founder of the American Physiological Society, studied for 2 years with Ludwig at the new Leipzig laboratory. In comparison with the poor facilities he had seen in France, Bowditch consid- 
ered Ludwig's lab "a perfect model" for the research institutions needed in America [Fye, 1987, p. 103]. Discussion was already underway for the reform of Harvard's medical education, and, after returning from Europe, Bowditch became director of Harvard's new physiology laboratory in 1872 .

Reversing a tradition that had stressed practical skills in medical education, the lab's aim was to train men for science [Fye, 1987]. In Germany, Bowditch had modified Ludwig's kymograph, enabling it to depict time automatically. He also brought "quite a quantity of apparatus" back with him, even building his own devices once the lab was running [Cannon, 1922; Fye, 1987, p. 112]. Harvard's was the "first physiological laboratory for the use of students in the United States" [Cannon, 1922, p. 186], and it fully embodied the concepts and methods that Bowditch had experienced in Leipzig. Techno-organic animal-machine standards were becoming the norm.

\section{America's Commercialization of Test Animals}

Between 1910 and 1930, as the laboratory tradition spread across the USA, the first commercially available living rodents were bred and sold for research in America. They were the Wistar Institute's strains of domesticated rats and the strains of mice developed at the Jackson Memorial Laboratories. By their promoters, these animals were not termed "model animals," they were instead called "standards." The latter term had and has several meanings [Kirk, 2012; Friese, 2018]. Initially, it referred to the effort to establish uniform conditions and materials across different laboratories, an effort that would enhance the precision and replicability of experimental findings. As such, animal standards were a huge advance. However, the term took on different meanings that are well illustrated by Milton Greenman's use of the evolutionarily oxymoronic phrase "standard animal" [Clause, 1993].

In 1905, Greenman was named Director of the Wistar Institute of Anatomy and Biology in Philadelphia. Founded as an anatomy museum, beginning in 1892, the Wistar was reorganized to emphasize research. It would stress experiments on the brain, about which Greenman [1905, p. 4] wrote, "no American institution has devoted special attention," and it would soon add a second emphasis on embryological development, including that of the human brain.

Greenman was a pioneer in standardizing the modern biology laboratory. He had been impressed with Frederick Taylor's [1903] Shop Management, which emphasized the economy generated by imposing "uniform standards" on the conditions of work. He was also impressed when the American Chemical Society and the US Bureau of Standards developed national standards for purifying chemical reagents. Chemistry's example and the precision and efficiency that Taylor promised would, Greenman wrote, "result in immense economies in science as well" [quoted in Clause, 1993, p. 341]. So, he standardized several aspects of the materials and methods used in the Wistar's new laboratories.

For Greenman (trained in medicine in the 1890s), these included "a standard or uniform animal within accepted limits of variation" [Greenman, quoted in Clause, 1993, p. 348] - Wistar's albino rats. Clause shows that he viewed selectively bred species as comparable to the standardized machine screw threads and pure chemicals then used in the railroads and in industry. They would be "a living analog to the pure chemicals that legitimated experimental science" [p. 348]. For Greenman, Wistar's rats were conceptual techno-organic hybrids: "uniform animals" that could interface with standards in housing, feeding, and technology to ensure precision in the study of brain development in a scientifically managed laboratory.

By 1906, Wistar's transition into a premier laboratory for experimentation was well underway, as luxuries such as hot and cold water and refrigeration were introduced. That year, Wistar's new Scientific Director, the prominent neurologist Henry Donaldson [Lazar, 2018], was hired to ensure the Institute's turn to neurology. Initially, Donaldson (Fig. 2) supported Greenman's effort. He even chose rats as the animals to be standardized. In 1897, the Swiss émigré neurologist Adolf Meyer, later America's premier academic psychiatrist [Lamb, 2014], had begun to breed albino rats for developmental studies in neuroanatomy. At about that time, Meyer convinced Donaldson that albino rats were ideal animals for exploring the development of mammalian brains [Logan, 1999; 2005]. The two men shared an interest in the value of precise science for enhancing human well-being, and they stressed rats because, like humans, they are omnivorous, cosmopolitan, and, perhaps most importantly, their brains develop relatively slowly [Logan, 1999, 2001, 2002]. Donaldson had determined that a precise 30 to 1 ratio characterized the relation between brain growth in humans and rats. With them he could implement an unprecedented quantification of brain development across the lifespan. Donaldson even brought a colleague - Shinkishi Hatai, who had worked on albinos in Chicago - and a few rats with him to Wistar. At this point, he was convinced that
74

Brain Behav Evol 2019;93:70-81 DOI: $10.1159 / 000500073$
Logan 


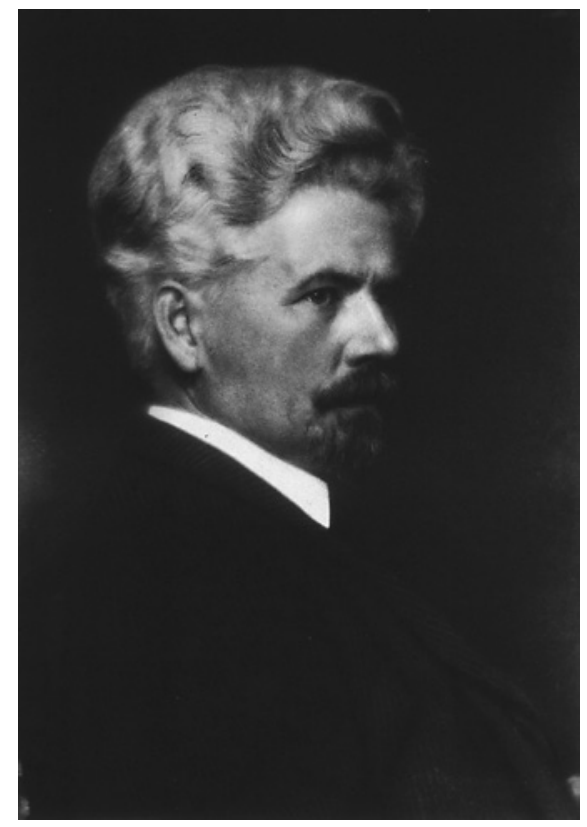

Fig. 2. Henry Herbert Donaldson (1857-1938), founding American neurologist (courtesy of Wikimedia Commons).

the choice of rats would be a fortunate and productive one.

This view crystallized when Donaldson encountered albinos during a 4-month European research trip in the summer of 1909 . His project aimed to compare brain growth across populations of wild gray rats. The animals were to be trapped by rat-catchers in each of several cities that were home to prominent physiology or neurology labs. One of Donaldson's first stops was in Vienna; but he was frustrated when very few wild rats could be found there. A colleague put him in touch with scientists at Vienna's Biologische Versuchsanstalt (Institute for Experimental Biology) - the BVA [Müller, 2017a]. The Director of the BVA, zoologist Hans Przibram, was doing experiments comparing the impact of high external temperatures on normal and heat-exposed albino rats during development [Müller, 2017b]. Donaldson described these experiments as "remarkable." While there, he worked on Przibram's albinos and even arranged for several brains to be sent to London for analysis. He had modified his research plan to build albinos into his comparisons [Greenman, 1909]. Donaldson, nonetheless, remained cautious about the wisdom of Greenman's approach. As Wistar's breeding program began, he feared a rupture with Greenman. In 1911, Donaldson wrote in his diary: "G[reenman] cannot adjust to the vacillations of biological work - the regularity of machines is more to his mind."

Commercial Rodents: Standards and Models
Although Donaldson and his Wistar colleagues completed almost 30 years of research on the brains of albino (and wild) rats, the concept of an unchanging animal technology quickly seemed incongruous.

In 1892, Isaac Wistar had endowed the Wistar as an institution separate from the University of Pennsylvania [Clause, 1993; Lazar, 2018]. At its twentieth anniversary celebration as the Wistar Institute of Anatomy and Biology, zoologist C.E. McClung [1925] noted General Wistar's great insight: " $[\mathrm{He}]$ endowed a research institution in biology" [p. 71, my italics]. Wistar's research was not biomedical; rather, it encompassed a broader focus worthy of adding "biology" to its name. Donaldson shared this goal, and as he prepared the second edition of his rat handbook, which presented the research on grays and albinos done in his group up to 1924 [Lazar, 2018], he noticed that, in less than a decade, the carefully standardized measures taken on the animals (at comparable ages and under constant conditions of testing and maintenance) had changed. The book would stand; but in its preface, Donaldson wrote of the rats: "One hastens ... [to] disclaim the suggestion that they furnish standards of the same type as are to be had in the physical sciences. In the very nature of the case such accuracy and constancy is [sic] unattainable for all animals at all times are in a state of flux. ... Really all that can be said in the way of apology ..., is that 'once upon a time' there was a group of albino rats ... which had the various characters with the values here recorded" [Donaldson, 1924, p. xi]. Even Greenman conceded that, despite his efforts, "the results were not what we had expected (e)ven with a diet as ... uniform as may be devised, with environmental conditions as uniform as may be secured. ... All these, together with the variable and undeterminable state or conditions of the albino rat itself ... result in a constantly changing organism" [cited in Clause, 1993, p. 348].

But it was too late. The Wistar also published five premier biology journals that advertised Donaldson's handbook across the USA and around the world. The actual breeding, done through Helen Dean King's inbreeding research, used brother-sister matings of "individuals with desirable characteristics." King had produced "a superior strain of inbred albino rats ... the best known of the Wistar strains because of their health, vigor, and other qualities" [both quotes, Clause, 1993, p. 42]. By the 1920s, the Wistar had sold over 40,000 rats to labs across the USA, and just as many were used there. The Institute trademarked the name WISTARAT ${ }^{\circledR}$ in 1942 , to distinguish its quality strains from other brands then also commercially available [Clause, 1993]. 


\section{Mice, Production, and Big Science}

By the 1940s, "Big Science" was slowly emerging in the USA [Capshew and Rader, 1992]. The term was coined in 1961, but the stage was set in the 1930s, when Ernest Lawrence's invention of the cyclotron triggered huge changes in physics that - with the outbreak of World War II - led to the Manhattan Project [Hiltzik, 2015]. Coordinated scientific assaults on important biomedical problems grew in parallel with this unprecedented government involvement in science, and mice were a part of it. As early as the 1930s, commercially bred strains of mice were being presented as keys to America's so-called "war on cancer." In 1937, Life Magazine published an article with the heading "US Science Wars against Unknown Enemy: Cancer." In it, the prominent US geneticist Clarence Cook Little was pictured as one of 10 scientists commanding that war. The article included graphic pictures of a cancerous heart, a cancerous lung, cancerous mice, and a mid-coronal cross-section of the brain of a 5-yearold girl who had died of metastasized kidney cancer. Much of her left parietal hemisphere appeared as just a large black hole. Stating that only surgery and radiation were effective in treating cancer and that radiation might either cure or cause the disease, the article was almost guaranteed to frighten Life's readers.

Little was a star of American science. Trained at Harvard, by age 36, he had resigned as President of the University of Michigan to become director of the Jackson Memorial Laboratories in Bar Harbor, Maine. The Jackson Labs were named for Roscoe Jackson, founder of the Hudson Motor Car Company and one of Little's several Detroit benefactors [Rader, 2004]. Jackson himself even noted the importance of standard animals "for making biomedical research more like a Detroit factory assembly line" [Rader, 2001].

With funding from the automotive industry, Little began a program to breed and sell what collectively became the JAX mice to labs across the USA. The Life article was one part of a broader marketing campaign in which genetically pure strains of mice were presented as essential to solving America's growing concern about the health impact of cancer. That campaign also drew on several public health agencies to target the views of the public and the US Congress; it even included a publicity film, $R_{x}$ Mouse [Rader, 2004].

In outlets from Time, Colliers, Good Housekeeping, Newsweek, and Fortune, to Scientific American, the American Naturalist, and the American Journal of Cancer, Little promoted JAX mice to an amazingly wide-ranging au- dience. Consistently stressing basic research, he used a "rhetoric of warfare" [Rader, 2004, p. 147] to present mice as the scientific keys to better health. They were "the troops which literally by the tens of thousands occupy posts on the firing line of investigation (into the) ... nature and cure of cancer" [Little, 1935, quoted in Rader, 2004, p. 135]. Between 1930 and 1932, in response to an economic crisis in the lab and the Great Depression, Little's priorities for the Jackson Labs had begun to shift. Initially, the mice were used internally in research on the genetics of cancer. In 1932, Little received a request from a Public Health Service cancer pathologist (collaborating with Harvard) for 500 "high-cancer strain" mice. JAX Labs contracted to sell him the animals for 50 cents per mouse [Rader, 2004]. Because the lab was already producing more mice than JAX could use, animals were being destroyed. Selling them instead was a good deal. And as more mice were requested, Little's attention turned more and more to public advocacy of the benefits of breeding and selling mice.

In 1929, Little became president and managing director of the American Society for the Cure of Cancer (ASCC - forerunner of the American Cancer Society). There and at the National Research Council's Committee for Experimental Plants and Animals, Little regularly defended the diversion of government funds to animal research as well as the need for centralized animal production centers (these could minimize federal costs) as against the more traditional focus on treatment. So, as the fear of cancer peaked, Congress took coordinated action [Rader, 2004].

In June 1937, Congress agreed to fund the National Cancer Institute Act. The funding package included the first federal extramural grant program funding biomedical research. Little himself testified before a joint congressional committee, recommending how the funds should be used. Congress must "insure a constant and adequate supply of controlled, known material on which investigations could be carried out." Assuring Congress that JAX mice were available, he added: "We can produce as nearly a chemically pure animal ... as it is possible to produce" [both quotes from Rader, 2004, p. 155]. After all, in 1 year JAX had just sold over 60,000 mice for research.

The NCI Act also authorized a board of scientists, the National Advisory Cancer Council, that would determine how the funds should be spent. After his congressional testimony, Little was asked to join it. He then applied for the funds that the group oversaw. He proposed not basic research, but - counter to the program's aims - support for the JAX breeding effort. The animals, he said, "are now recognized as standard materials" [quoted in Rader,
Brain Behav Evol 2019;93:70-81 DOI: $10.1159 / 000500073$
Logan 
2004, p. 156]. Furthermore, he could double JAX mouse production and give government-funded labs first priority on the animals. Lacking any alternative, the Council recommended funding.

However, the Lab's reputation suffered. One Rockefeller Institute program officer declined grants for the Jackson Labs in the 1950s because, he said, over $88 \%$ of the funds already granted had been used to maintain the breeding colony; only $12 \%$ went for actual research. Jackson Labs' core now consisted "in a supply service of standardized mouse strains” [quoted in Rader, 2004, p. 216].

\section{America's Engineering Ideal}

Confusion surrounded the science of evolution during a period termed the "eclipse" of Darwinism [Bowler, 1983], which, to varying degrees, occurred between about 1890 and 1920. Ronald Numbers [1998] has shown that in America most naturalists elected to the National Academy of Sciences before 1900 accepted the idea of species change and the great age of the earth, but they rejected natural selection. Several major American biologists instead promoted their own theories of evolution, theories that were often based in inherent and forward-moving directional progress. These beliefs reflected the scientists' trust in inevitable biological progress that would consistently bring improved human morality and health - a trust that was partly a product of America's strong religious foundation [Numbers, 1998].

In the 1990s, in his study of the émigré physiologist Jacques Loeb, historian Philip Pauly [1990] proposed "an engineering ideal" in American physiology. It emerged, he wrote, at about the same time - around 1900 - and it stemmed from physiology's biomedical origin. That tradition had analyzed bodily function in terms of a "polarity" between the normal and the pathological. In this context, experiments usually created "an abnormal process that could lead to knowledge through comparison with the known normal situation .... Outside the medically defined framework, physiological experimentation made no sense; there was no conceptual place for something neither healthy nor diseased" [Pauly, 1990, p. 17]. Amid American debates about the direction of progressive evolution, this meant there was no place for evolutionary analysis. Reinforced by Du Bois-Reymond's physicalist neurophysiology, the engineering ideal provided what seemed a far more scientific alternative. American evolutionary thinking was bathed in such imprecision that physiologists like Loeb abandoned it in favor of the engineering ideal.

Commercial Rodents: Standards and Models
Robert Kirk's [2008] exploration of the rise and commercial breeding of standardized guinea pigs in mid-century Great Britain shows that even in Darwin's homeland, albeit in a vastly different social context, industrial orientations stressing standardization guided their breeding effort too. Clarence Little's approach, his advocacy of mice, and their reception reflect an expanding engineering ideal in biomedicine - "industrially orientated biological science" [Kirk, 2008, p. 289] - supported, in America, by biomedical commercialism, Little's leveraging of government agencies and Congress for "Big Cancer Science," and an automotive regard for mass production. Undergirded by a commercial engineering ideal, Little's mouse genetics prevailed in part because pure-bred mice, as thousands of little flags, captured people's imaginations as solutions to one of their greatest fears: cancer.

Little's cancer project ultimately failed. But after 1945, the Manhattan Project embodied Big Science that worked and worked like nothing else. Los Alamos may seem far from the commercial use of a few test animals, but the two are connected by practical and historical patterns. In both Berkeley (Lawrence's headquarters) and Los Alamos, the health effects of radiation were a major concern. John Lawrence, Ernest's brother, who had studied pituitary tumors in mice at Harvard, became interested in the biomedical effects of radiation. In 1935, he brought several mice to the Lawrence Radiation Labs, where they were used to explore the effects of radiation on mouse tumors [Hiltzik, 2015]. ${ }^{2}$ The Manhattan Project even later housed a Medical Station probing the health dangers of radioactivity. There, several zoologists examined plutonium toxicity in animals [Howes and Herzenberg, 2003]. Rodents had become a part of the engineering ideal's greatest victory.

\section{“Models" and Knowledge Transfer}

Historians and sociologists of science commonly stress that test organisms are embedded in larger experimental systems. Examining neuroscience, for example, Michael Lynch [1988] distinguishes between test rats as laboratory-produced "analytical" animals and the common "naturalistic" rats familiar to nonscientists. The latter are anthropomorphized, while the former often have no subjective attributes, but become place holders for "a few tiny

\footnotetext{
${ }^{2}$ Little's mice were later used in radiation biomedicine by Jackson scientist, William Russell, who left JAX for the Oak Ridge National Laboratory [see Rader, 2004].
} 
fragments of brain tissue" [p. 270]. One result is a reduced abstraction of the animal; it becomes "a hypothetical sequence of events in a generalized brain" [p. 272]. Amann [1994] similarly stresses the "second" nature of inbred mouse models used in analyses of DNA in molecular biology. Models are no longer "natural objects that ... divulge something of their inner cohesion" [p. 278]. Rather, they are transformed by their relation "to the technical system into which they are embedded [p. 278] ... (and) integrated into a research ecology and economy that demands new living functions of its inhabitants" [p. 279]. These mice cannot even be considered a new species; they are "technofacts," modern techno-organic constructions as akin to electronic circuitry as to mice inhabiting the basements of homes [see also Weber, 2007].

Observing the dynamics of model building in contemporary behavior genetics, Nelson [2013, 2016] describes how "models" are continually re-adjusted to resolve problems that emerge during the course of research. Nelson, however, redefines the "model" to include not just mice and their experimental setups and housing. Importantly, she adds to the "model" features of the human phenomenon under investigation.

Nelson [2013] proposes that all are from the outset woven together into a dynamic and empirically based "epistemic scaffold." This is a complex of assumptions, definitions, arguments, evidence, animals, and their props some regarding the animal and some its target - that undergirds knowledge production and "substantiates the use of the model" [Nelson, 2013, p. 8] and the transfer of the knowledge gained. The scaffold (a metaphor valued for connotations of work in progress) frames scientists' research and guides the nonlinear, but regular dialogues through which investigators "gradually craft a particular framing of the human disorder and of the practice of behavior genetics along with an argument for their model" [Nelson, 2013, p. 21]. So, scientists do not just hope their mouse models will succeed, rather they work and tinker with their set-ups, their definitions, and their phenomena to make it happen. And from the beginning, empirical data on the human target are built into the model complex.

In mouse models of human anxiety disorders, for example, the so-called elevated plus maze is critical to the model's plausibility. The maze presumably reflects a setting in which approach-avoidance conflicts pit a tendency to openly explore against a tendency to avoid the deadly risks of predation. Without this particular maze, mice would not be convincing models of human anxiety. The maze extends the plausibility of mice, not to humans in general (as, say, mammals), but specifically to human anxiety as understood in approach-avoidance contexts. Furthermore, data from different domains on both mice and humans are built into the scaffold to support claims about the validity of the mice and their behavior. Findings from pharmacology, for example, are used along with maze-running to justify the utility of maze results. The drug Librium (an anxiolytic) increases time in open areas of the maze, while caffeine (an anxiogenic) decreases it. These murine findings correspond to those measured in humans, which are also part of the model's logic. Together they strengthen the complex, showing that interpretations of a mouse's state as reflecting, for example, merely high activity levels, can be discounted in favor of those indicating something more like human anxiety - a phenomenon that modelers do not attribute to mice without some concern. Changes are made cautiously, as investigators expand and reconfigure the scaffold to provide support for transfer.

Most changes in the model result from challenges generated from within the mouse behavior genetics community. These trigger more adjustment, as responses to the informed criticism of colleagues sometimes strengthen, sometimes weaken the claims. Even staunch supporters, however, acknowledge that relevant aspects of the human phenomenon of interest are often excluded from well-articulated models. Nelson notes this can create dilemmas. For example, one tension surrounding mouse models of alcohol addiction is the observation that mice, unlike humans, regulate their alcohol intake like food [Ankeny, et al., 2014; but see Hopf and Lesscher, 2014]. In the study of anxiety disorders, language usage may also be altered that weakens the parallel between animal and human mouse maze behavior becomes "anxiety-like" rather than "anxious"; "depression" is adjusted to "depression-relevant." Yet despite this caution, rarely do such criticisms stop the investigative enterprise. Rather, even as the model changes in response to informed criticism, it continues to shape future research in a very similar mold [Nelson and Panofsky, 2018].

\section{Evolution, "Standards," and "Models"}

The dominant linguistic usage of the last 50 years has employed the common phrases "animal model" and "model animal" to label test animals. However, these usages appear to have emerged rather late, long after pioneers such as Greenman, Donaldson, and Little established a methodological trend based in the value of standardization. What changed to transform "standard
Brain Behav Evol 2019;93:70-81 DOI: $10.1159 / 000500073$
Logan 
animals" into "models," a usage that has largely overshadowed the serious concerns expressed by Donaldson and Greenman in the early twentieth century? A document entitled Animal Resources: A Research Resource Directory, published in 1977 by the US Government (NIH Publication No. 77-1341), offers some clues about how the government framed the context in which the usage "model animals" emerged. Aimed at enhancing resources in "Laboratory Animal Science" through the Institute of Laboratory Animal Research, it proposed an "animal models and genetic stocks information exchange." The objective of the exchange was to "develop and make available ... scientific and technical information, ... to improve the availability, quality, and utilization of laboratory animals," and to respond to investigators' requests about the "existence and location of specific animal models" [p. 27]. In it, descriptions of projects already being funded were presented as guides for new investigators who might seek "assistance or collaboration involving animals" [p. 5].

Its content shows two things. First, "animal models" come up often and almost always in a biomedical context. However, as in the above quotes, the phrases "animal models" and "laboratory animals" are used interchangeably. "Animal models" are also mentioned in specific proposals. For example, one investigator described his goal as: "Discovery and characterization of animal models of extraordinary potential for the study of analogous human health programs." Furthermore, although mice are included, so is a surprisingly diverse array of other species. Seven Regional Primate Centers are presented as guides (listing many primate species), and the non-primate test animals mentioned include many species of frogs as well as hamsters, rabbits, cats, dogs, guinea pigs, goats, mink, chinchillas, alligators, squid, and purple sea urchins. One project proposed using 300 species of Drosophila; another, Zucker fatty rats. The document's goals stress the importance of "hundreds of vertebrate and invertebrate species ... including new models in development" [p. 7]. No rhyme or reason is apparent in the animals included; rather, the bureaucracy seems to simply endorse the animals already in use by funded investigators. Building on the principle applied to primate centers, the greater concern was a coordinated governmental effort to enhance biomedical progress through animal access - Big Science for test animals. The species represented may simply have been labelled "models" by program administrators, as if any species with a potential to benefit human health qualified as a "model." The phrase may reflect nothing beyond the hopeful, but arbi- trary use of the synonym for "lab animal" that most justified the bureaucracy's biomedical intent.

Scholars in the history and philosophy of science have developed several alternative accounts of the organisms used in and transformed by the laboratory [e.g., Keller, 2000; Creager, 2007; Rheinberger, 2010, 2015; Boudry and Pigliucci, 2013; Nicholson, 2013; Germain, 2014; Green et al., 2018]. They distinguish various uses of animals, though not usually within an evolutionary framework. Scientists' accounts, however, often stress the absence of the modern evolutionary perspective in today's model animal tradition. Representing two different scientific disciplines, Preuss [2000] and Bolker [2009, 2019] each similarly distinguish two kinds of models: those used in empirical analyses of circumscribed, but quite widespread processes within a larger phyletic taxon, and those employing an animal or preparation to represent a particular phenomenon in a given target, usually humans. Each author develops an evolutionary framework for the use of the latter, an intended model - labelled by Bolker "surrogates" and by Preuss "model animals." Preuss applies primate and rodent phylogenies to the evolution of cortical organization in mammals, while Bolker extends the logic of ancestral descent and ecological convergence to several types of inferences appropriate when using homologies versus analogies.

However, for both scientists, the validity of "surrogates"/ "model animals" is not assumed by default; rather, it depends upon an indispensable evolutionary logic or empirical pattern dictated by branching phylogeny and/ or ecology as it is applied to particular phenotypes [see also Gilbert, 2009; Hopgood, 2011; Preuss, 2011]. Such efforts by scientists carefully underscore the view that the lure of Big Science guided by an engineering ideal, by an oddly passive hunt for similarities bathed in "species neglect" or outmoded evolutionary concepts [Preuss and Robert, 2014], and/or by a potential for human benefit must not obscure the modern evolutionary logic behind how we understand one animal using many others.

\section{Acknowledgements}

The author is extremely grateful for the stimulating research and discussions presented at the 2018 Karger Workshop "The Role of Species Diversity in Neuroscience," for excellent suggestions on an earlier draft of the manuscript by an anonymous reviewer, Todd Preuss, and Georg Striedter, and for ongoing stimulating discussions with Todd Preuss about how animals are used in experiments. 


\section{Statement of Ethics}

The author has no ethical conflicts to disclose.

\section{Disclosure Statement}

The author has no conflicts of interest to declare.

\section{References}

Amann K. Menschen, Mäuse und Fliegen. Eine wissenssoziologische Analyse der Transformation von Organismen in epistemische Objekte. In: Hagner M, Rheinberger H, WährigSchmidt B, editors. Objekte, Differenzen und Konjunkturen. Experimentalsysteme im historischen Kontext. Berlin: Akademie; 1994. pp. 259-89.

Ankeny RA, Leonelli S. What's so special about model organisms? Stud Hist Philos Sci. 2011; 42(2):313-23.

Ankeny RA, Leonelli S, Nelson NC, Ramsden E. Making organisms model human behavior: situated models in North-American alcohol research, since 1950. Sci Context. 2014 Sep; 27(3):485-509.

Benson K. The Naples Stazione Zoologica and its impact on the emergence of American marine biology. J Hist Biol. 1988;21(2):331-41.

Bolker JA. Exemplary and surrogate models: two modes of representation in biology. Perspect Biol Med. 2009;52(4):485-99.

Bolker JA. Selection of models: evolution and the choice of species for translational research. Brain Behav Evol. 2019. DOI: https://doi. org/10.1159/000500317.

Borck C. Toys R Us. Models and metaphors in brain research. In: Choudhury S, Slaby J, editors. Critical Neuroscience: A Handbook of the Social and Cultural Contexts of Neuroscience. London: Blackwell Publishing; 2012.pp. 113-33.

Boudry M, Pigliucci M. The mismeasure of machine: synthetic biology and the trouble with engineering metaphors. Stud Hist Philos Biol Biomed Sci. 2013 Dec;44(4 Pt B):660-8.

Bowler P. The Eclipse of Darwinism. Anti-Darwinian Evolution Theories in the Decades around 1900. Baltimore: Johns Hopkins University Press; 1983.

Brain RM. The Pulse of Modernism. Physiological Aesthetics in Fin-de-Siècle Europe. Seattle: University of Washington Press; 2016.

Canon WB. Biographical memoir Henry Pickering Bowditch, 1840-1911. Biogr Mem Natl Acad Sci. 1922;XVII:181-96.

Capshew JH, Rader KA. Big Science: Price to the present. Osiris. 1992;7:3-25.

Clause BT. The Wistar Rat as a right choice: establishing mammalian standards and the ideal of a standardized mammal. J Hist Biol. 1993;26(2):329-49.

Creager AN, Lunbeck E, Wise MN, editors. Introduction. Science without laws: model systems, cases, exemplary narratives. Durham: Duke University Press; 2007.
De Chadarevian S. Die 'Methode der Kurven' in der Physiologie zwischen 1850 und 1900. In: Hagner M, Rheinberger HJ, editors. Die Experimentalisierung des Lebens. Experimentalsysteme in den biologischen Wissenschaften 1850/1950. Berlin: Akademie Verlag; 1993. pp. 28-49.

De Chadarevian S, Hopwood N, editors. Models: The Third Dimension of Science. Palo Alto: Stanford University Press; 2004.

Dierig S. Engines for experiment: laboratory revolution and industrial labor in the nineteenthcentury city. Osiris. 2003;18:116-34.

Dierig S. Wissenschaft in der Maschinenstadt. Emil du Bois-Reymond und seine Laboratorien in Berlin. Göttingen: Wallstein Verlag; 2006.

Donaldson HH. The Rat. Data and Reference Tables for the Albino Rat (Mus Norvegicus Albinus) and the Norway Rat (Mus Norvegicus). Philadelphia: Wistar Institute of Anatomy; 1924.

Donaldson HH. Unpublished "Diaries", Henry Donaldson papers. Philadelphia: American Philosophical Society Archives; quote from 1911 Oct 10.

Du Bois-Reymond E. Address reprinted in Popular Science Monthly; wikisource: wikisource. org/wiki/Popular_Science_Monthly/Volume_23/June_1883/Darwin_and_Copernicus. 1883 .

Fangerau H. Experimental biology and the biomedical ideal around the year 1900. In: Müller GB, editor. Vivarium. Experimental, Quantitative, and Theoretical Biology at Vienna's Biologische Versuchsanstalt. Cambridge: MIT Press; 2017. pp. 77-94.

Finkelstein G. Emil Du Bois-Reymond. Neuroscience, Self, and Society in Nineteenth-Century Germany. Cambridge (MA): MIT Press; 2013. https://doi.org/10.7551/mitpress/ 9543.001.0001

Florey E. The zoological station at Naples and the neuron: personalities and encounters in a unique institution. Biol Bull. 1985;168 (Suppl):137-52.

Friese C. Co-producing animal models and genetic science. In: Gibbon S, Prainsack B, Hilgartner S, Lamoreaux J, editors. Routledge Handbook of Genomics, Health and Society. 2nd ed. London: Routledge; 2018. pp. 273-82.

Fye WB. The Development of American Physiology. Scientific Medicine in the Nineteenth Century. Baltimore: John Hopkins University Press; 1987.

Germain PL. From replica to instruments: animal models in biomedical research. Hist Philos Life Sci. 2014 Aug;36(1):114-28.
Gilbert S. The adequacy of model systems for evodevo: Modelling the formation of organisms/ modeling the formation of society. In: Barberousse A, Morange $M$, Pradeu M, editors. Mapping the Future of Biology: Evolving Concepts and Theories. Berlin: Springer Nature; 2009. pp. 57-68.

Green S, Dietrich MR, Leonelli S, Ankeny RA. 'Extreme' organisms and the problem of generalization: interpreting the Krogh principle. Hist Philos Life Sci. 2018 Oct;40(4):65-82.

Greenman M. Director's Annual Report. Wistar Institute. Philadelphia: The Wistar Library; 1905. p. 4.

Greenman M. Director's Annual Report. Wistar Institute, Appendix B. Philadelphia: The Wistar Library; 1909.

Guillery RW. Observations of synaptic structures: origins of the neuron doctrine and its current status. Philos Trans R Soc Lond B Biol Sci. 2005 Jun;360(1458):1281-307.

Hiltzik M. Big Science. Ernest Lawrence and the Invention that Launched the Military Industrial Complex. New York: Simon and Schuster; 2015 .

Holmes FL. The old martyr of science: the frog in experimental physiology. J Hist Biol. 1993; 26(2):311-28.

Hopf FW, Lesscher HM. Rodent models for compulsive alcohol intake. Alcohol. 2014 May; 48(3):253-64.

Hopgood N. Vertebrate embryogenesis: embryological, cellular and genetic methods. In: Pelegri FJ, editor. Methods in Molecular Biology 770. New York: Humana Press; 2011. pp. $1-20$.

Howes R, Herzenberg C. Their Day in the Sun: Women of the Manhattan Project. Philadelphia: Temple University Press; 2003.

Keller EF. Models of and models for: theory and practice in contemporary biology. Philos Sci. 2000;67:S72-86.

Kirk RG. 'Wanted-standard guinea pigs': standardisation and the experimental animal market in Britain ca. 1919-1947. Stud Hist Philos Biol Biomed Sci. 2008 Sep;39(3):28091.

Kirk RG. "Standardization through mechanization". Germ-free life and the engineering of the ideal laboratory animal. Technol Cult. 2012 Jan;53(1):61-93.

Kohler RE. Lords of the fly. Drosophila Genetics and the Experimental Life. Chicago: University of Chicago Press; 1994.

Lamb SD. Pathologist of the Mind: Adolf Meyer and the Origins of American Psychiatry. Baltimore: Johns Hopkins University Press; 2014.
80

Brain Behav Evol 2019;93:70-81

DOI: $10.1159 / 000500073$
Logan 
Lazar JW. Henry Herbert Donaldson's (18571938) contribution to an organized approach to the experimental study of the mammalian central nervous system. J Hist Neurosci. 2018 Oct-Dec;27(4):311-32.

Lenoir T. Farbensehen, Tonempfindung und der Telegraph. Helmholtz und die Mäterialität der Kommunikation. In: Hagner M, Rheinberger $\mathrm{H}$, editors. Die Experimentalisierung des Lebens. Experimentalsysteme in den biologischen Wissenschaften 1850/1950. Berlin: Akademie Verlag; 1993. pp. 50-73.

Lenoir T. Revolution from above: the role of the state in creating the German research system, 1810-1910. Am Econ Rev. 1998;88:22-7.

Logan CA. The altered rationale for the choice of a standard animal in experimental psychology: Henry H. Donaldson, Adolf Meyer, and "the" albino rat. Hist Psychol. 1999 Feb;2(1): $3-24$.

Logan CA. "[A]re Norway rats... things?”: diversity versus generality in the use of albino rats in experiments on development and sexuality. J Hist Biol. 2001;34(2):287-314.

Logan CA. Before there were standards: the role of test animals in the production of empirical generality in physiology. J Hist Biol. 2002; 35(2):329-63.

Logan CA. The legacy of Adolf Meyer's comparative approach: Worcester rats and the strange birth of the animal model. Integr Physiol Behav Sci. 2005;40(4):169-81.

Lynch ME. Sacrifice and the transformation of the animal body into a scientific object: laboratory culture and ritual practice in the neurosciences. Soc Stud Sci. 1988 May;18(2):26589.

Maienschein J. Transforming Traditions in American Biology, 1880-1915. Baltimore: Johns Hopkins University Press; 1991.

McClung CE. Changes in methods of biological research as pursued by museums and the possibilities of the future. Bull Wistar Inst Anat Biol. 1925;6:69-75.
Müller GB. Biologische Versuchsanstalt: an experiment in the experimental sciences. In: Müller GB, editor. Vivarium. Experimental, quantitative, and theoretical biology at Vienna's Biologische Versuchsanstalt. Cambridge: MIT Press; 2017a. pp. 3-18.

Müller GB. The substance of form: Hans Przibram's quest for biological experiment, quantification, and theory. In: Müller GB, editor. Vivarium. Experimental, quantitative, and theoretical biology at Vienna's Biologische Versuchsanstalt. Cambridge: MIT Press; 2017b. pp. 135-64.

Nelson NC. Modeling mouse, human, and discipline: epistemic scaffolds in animal behavior genetics. Soc Stud Sci. 2013;43(1):3-29.

Nelson NC. Model homes for model organisms: intersections of animal welfare and behavioral neuroscience around the environment of the laboratory mouse. Biosocieties. 2016; 11(1):46-66.

Nelson NC, Panofsky A. Behavior genetics: boundary crossings and epistemic cultures. In: Gibbon S, Prainsack B, Hilgartner S, Lamoreaux J, editors. Routledge handbook of genomics, health and society. 2nd ed. Abingdon: Routledge; 2018.

Nicholson DJ. Organisms $\neq$ Machines. Stud Hist Philos Biol Biomed Sci. 2013 Dec;44(4 4 Pt B): 669-78.

Normandin S, Wolfe CT, editors. Vitalism and the scientific image in post-enlightenment life science: 1800-2010. Dordrecht: Springer; 2013. https://doi.org/10.1007/978-94-0072445-7.

Numbers RL. Darwinism Comes to America. Cambridge: Harvard University Press; 1998.

Pauly PJ. Controlling Life. Jacques Loeb and the Engineering Ideal in Biology. Berkeley: University of California Press; 1990.
Pera M. The Ambiguous Frog: The Galvani-Volta Controversy on Animal Electricity. Princeton: Princeton University Press; 1992.

Preuss TM. Taking the measure of diversity: comparative alternatives to the model-animal paradigm in cortical neuroscience. Brain Behay Evol. 2000 Jun;55(6):287-99.

Preuss TM. The human brain: rewired and running hot. Ann N Y Acad Sci. 2011 May; 1225(S1 Suppl 1):E182-91.

Preuss TM, Robert JS. Animal models of the human brain. Repairing the paradigm. In: Gazzaniga M, Mangun R, editors. The Cognitive Neurosciences. 5th ed. Cambridge (MA): MIT Press; 2014. pp. 59-66.

Rader KA. The mouse's tale: Standardized animals in the culture and practice of technoscience. Cabinet. 2001;4. Available from: http:// www.cabinetmagazine.org/issues/4/themousestale.php.

Rader KA. Making Mice. Standardizing Animals for American Biomedical Research, 19001955. Princeton: Princeton University Press; 2004.

Rheinberger HJ. An epistemology of the concrete: twentieth century histories of life. Durham: Duke University Press; 2010. https://doi. org/10.1215/9780822391333.

Rheinberger HJ. Preparations, models, and simulations. Hist Philos Life Sci. 2015;36(3):32134.

Taylor FW. Shop management. New York: American Society of Mechanical Engineers; 1903.

Todes DP. Pavlov's Physiology Factory. Experiment, Interpretation, and Laboratory Enterprise. Baltimore: Johns Hopkins University Press; 2002.

Weber M. Redesigning the fruit fly: The molecularization of Drosophila. In: Creager AN, Lunbeck E, Wise MN, editors. Science Without Laws: Model Systems, Cases, Exemplary Narratives. Durham: Duke University Press; 2007. pp. 23-45. 